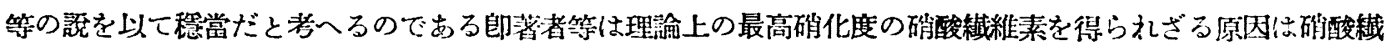

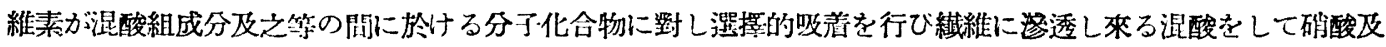
水に富むものたらしめ賔際硝化に參與する温酸をして濃度の低いものたらしむるにあると考へる而して其結果 としては硝化度が低いのみならず緎維の各部分に於て硝化度, 緎維素の加水分解度異り從つて綿の 1 本の紻維

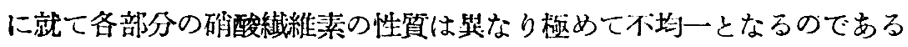

份ミ七儿の确化の初期に於て之に觸れる混酸の組成は前述の理由によりて晎る故に不可逆的の崩壤の程度も

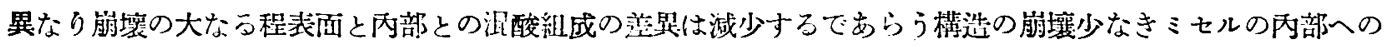

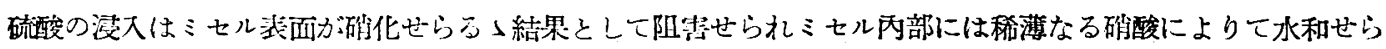

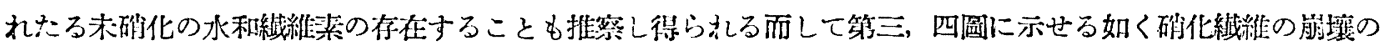

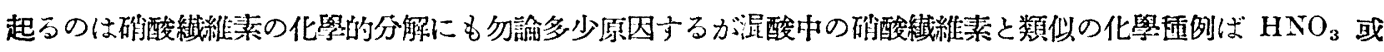
は $\mathrm{HNO}_{3} \cdot \mathrm{H}_{2} \mathrm{O}$ 等力緎維組織を膨潤崩壤せしもるにも原因する

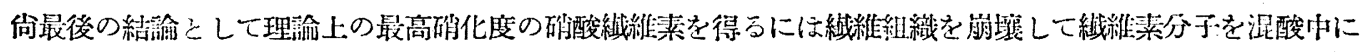
分散せしめて硝化を行ふを要する

結 論

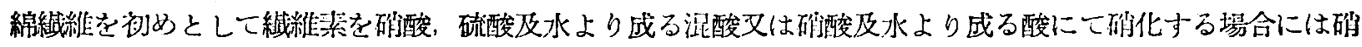

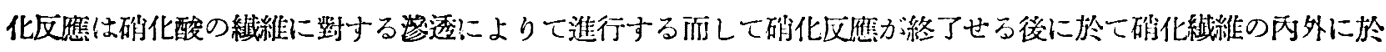
ける硝化酸つ成分を分析せるに硝化緎維の冈部に存在寸る酸は外部の酸よりも一般に水分に箩2确酸, 硫酸及

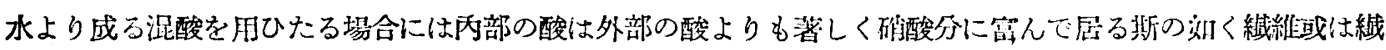

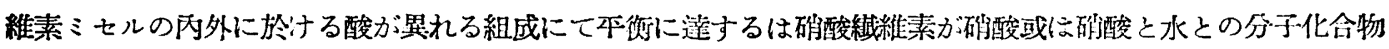
に對して强大なる遶擇性親和力を有するに原因する此の結果として水分の如何に少ない混酸を用ひても确化織

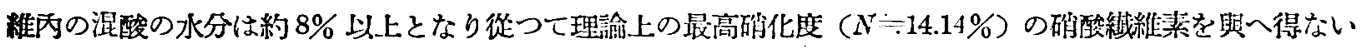

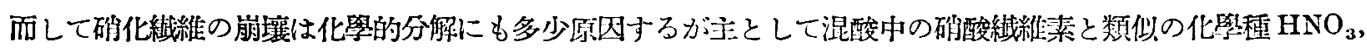

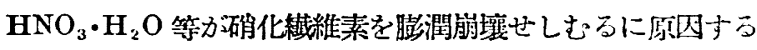

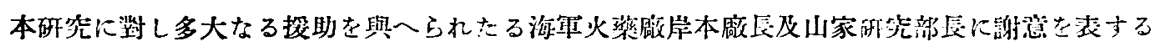

（大阪工業大學照用化學科研究室）（昭和七年一○月四日受理）

\title{
不飽和油脂の沃監化物並に沃臭化物に關する研究（第一報） 魚油より生ずる不溶性沃鹽化物並に沃臭化物に就て
}

\author{
上野 誠一・琵井 正昌 \\ 緒 \\ $\overrightarrow{\bar{i}}$
}

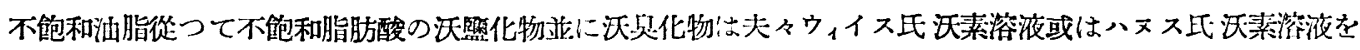
以て夫等の沃素價を测定する際に生ずるものなることは衃知の本密なり

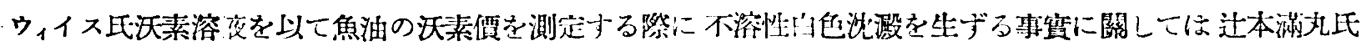

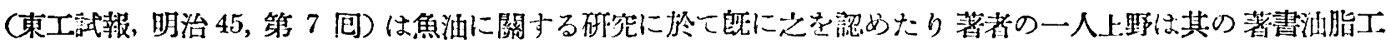

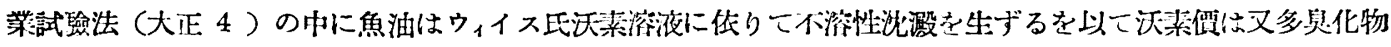

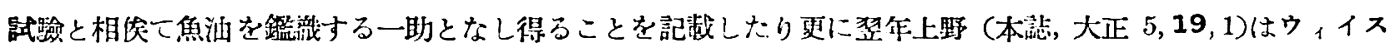




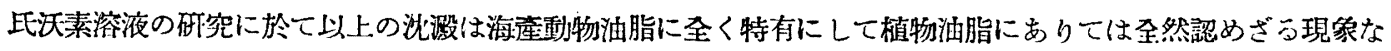
ることを明記したり最近に至り辻本滿丸氏 (本誌, 大正 $15,29,561$ ) は魚油脂肪酸きエーテルに溶解し之に濃 厚なるウィイス氏沃素溶液を加へて生ずる不溶性沈澱は高度不怉和酸の沃監化物に起因することを指摘し此の 沈没の你無を檢することを以て魚油檢出の新方法として提案せり

藷者等は今包ハヌス氏沃素溶液に依りても魚汕は沃臭化物の沈澱を生ずることを認めたり一臭化沃素に传る 此の種の沈澱に關しては未げ寒驗確證されたるものを見ず

玆に於て著者等は各種魚油脂肪酸より生ずる之等不溶性沃盟化物並に沃臭化物の組成を更に明兮にし份之等 の油脂化學矼究上に何等かの應用を見出さんと欲して實驗を行へり

實 驗 の 部

\section{(1) 不溶性沃鹽化物の製取}

魚油よりウィイス氏沃素溶夜に低りて生ずる不溶性白色沈澱の組成に關する研究資料として直按此の白色沈

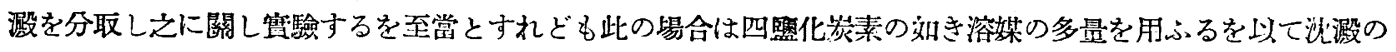
溶解量增加し其の收率僅少にして組成の砍究に資すべき分量に澾せしむるには甚だ困難なり依て著者等心魚油 を脂肪酸となし 0.5〜1g を取りエーテル 10〜15cc に溶解し1 モル立濃度の濃厚なるウィイス比液を泠却しつ

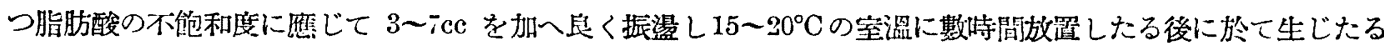

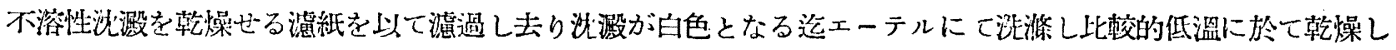
たり斯くして脂肪酸の不溶性沃監化物を裂取し此の物に就て椠驗を行ひたり之に用ひたる供試油は

\begin{tabular}{|c|c|c|c|c|}
\hline & & $\begin{array}{c}\text { 沃絜筧 } \\
\text { (ウィイス }\end{array}$ & 被化㵋 & 屈折率 $n_{D}^{20}$ \\
\hline thing & 油 & 180.4 & 195.9 & $1.4 S 05$ \\
\hline 钱 & 汭 & 108.4 & 186.9 & $1.47 \div 8$ \\
\hline & ラ月胑 & 148.4 & 195.1 & 1.4761 \\
\hline
\end{tabular}

及で鮊油より得たる高度不鉋和酸(中和價 180, 沃素 價 3:7）にして以上の脂肪酸より得たる不溶性沃監

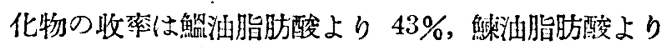

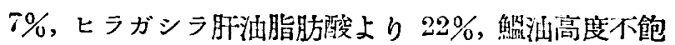
和酸より約 108\% を得たり何えも微細なる白色粉末にして加熱する時は $166^{\circ} \mathrm{C}$ を越へて漸次萛色し $170^{\circ} \mathrm{C}$ 附 近に於て融解することなくして黑變分解し紫色の蒸氣を生じたり

\section{(2)不溶性沃監化物の組成}

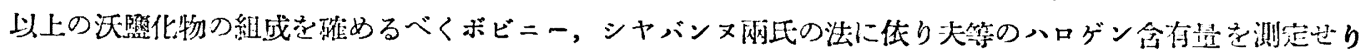
其の結果次の如し

\begin{tabular}{|c|c|c|c|c|c|c|}
\hline 沃㹂化 物 & 武 料 & $\mathrm{AgCl}(\mathrm{g})$ & $\operatorname{Ag} I(g)$ & $\mathrm{Cl} \%$ & $I \%$ & $\mathrm{Cl}: \mathrm{I}$ \\
\hline 鲋油脂肪唒より得たこもの & 0.3366 & 0.1937 & 0.2704 & 14.24 & 59.49 & $1: 1.1$ \\
\hline 㤵必油脂䏳酒 & 0.3440 & 0.2211 & 0.3891 & 15.89 & 60.81 & $1: 1$ \\
\hline 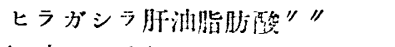 & 0.2219 & 0.1340 & 0.2461 & 14.94 & 59.96 & $1: 1.1$ \\
\hline 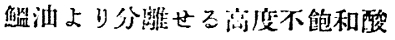 & 0.1893 & 0.0885 & - & 15.69 & - & - \\
\hline
\end{tabular}

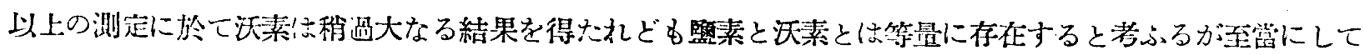

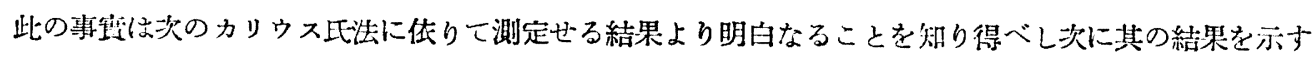

沃 筩 化物

鲑油脂肪酸より得たるもの 你油脂䏚陵 ヒラガシラ肪油脂㽖酸 ” "

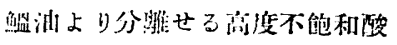

試 料

0.1728

0.1536

0.1218

0.1327
$(\mathrm{AgCl}+\mathrm{AgI})(\mathrm{g})$

0.2757

0.2515

0.2007

0.2180
$(\mathrm{AgCl}+\mathrm{AgI}) \%$

159.6

163.7

164.8

164.3 


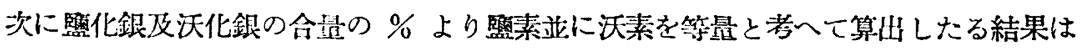

\begin{tabular}{|c|c|c|c|}
\hline 沃 鯂 化 物 & $(\mathrm{AgCl}+\mathrm{AgI}) \%$ & $\mathrm{Cl} \%$ & $\mathrm{I} \%$ \\
\hline 驷盃油脂肪酸より得たるもの & 159.6 & 34.96 & 53.55 \\
\hline 鱕油脂肪酸 & 163.7 & 15.35 & 54.96 \\
\hline ヒラガシラ肝油脂肘酸 " " & 164.8 & 15.45 & 55.31 \\
\hline 鰮油上り分踓せる高度不能和酸 & 164.3 & 15.40 & 55.14 \\
\hline
\end{tabular}

今魚油中に普通に出现すると考へられる高度不飽和酸並にリノレニン酸の沃冓化物に就て夫等のハロゲン含 有量を示せば

\begin{tabular}{|c|c|c|c|}
\hline & Cl & \multicolumn{2}{|c|}{$\mathrm{I} \%(\mathrm{AgCl}+\mathrm{AgI}) \%$} \\
\hline $\mathrm{C}_{18} \mathrm{H}_{28} \mathrm{O}_{2}(1 \mathrm{Cl})_{4}$ & 15.32 & 54.84 & 163.4 \\
\hline $\mathrm{C}_{20} \mathrm{H}_{32} \mathrm{O}_{2}(1 \mathrm{Cl})_{4}$ & 14.87 & E3.23 & 158.6 \\
\hline$\underset{\text { (鱼增 }}{\mathrm{C}_{22} \mathrm{H}_{34}} \mathrm{O}_{2}(1 \mathrm{Cl})_{5}$ & 15.52 & 55.56 & 165.5 \\
\hline 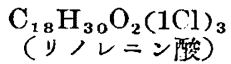 & 13.90 & 49.75 & 148.2 \\
\hline
\end{tabular}

以上の結果を對照するに魚油脂肪酸より得たる不 溶性沃監化物のハロゲン 含有量はリノレニン酸の夫 とは甚しく罢なり何れも高度不飽和酸のみより誘導 せられたることを示し辻本氏の寊驗結果に·更に確證 を加へたり從つて 魚油よりウィイス氏液に伡り沃素

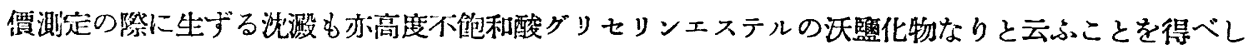

(3)不溶性沃臭化物の製取

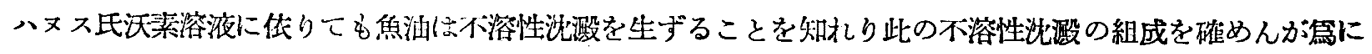
前述せる理由に依り前記魚油脂肪酸より其の不溶性沈泼を製取せり魚油脂肪酸 0.5 1 $\mathrm{g}$ をエーテル 10〜15ecに

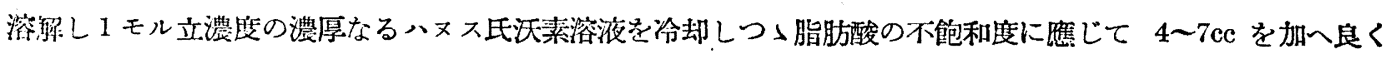

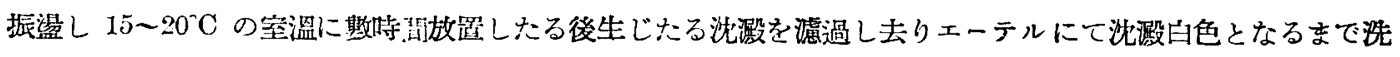
临し低溫にて乾燥ぜり斯くして得たる沃息化物は何れも微紅色を帶びたる粉末にして $140^{\circ} \mathrm{C}$ 越へて漸次着色

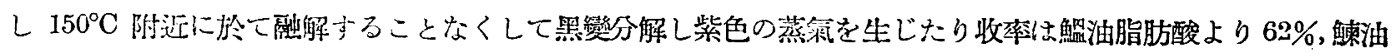
脂肪酸より $17 \%$ ，ヒラガシラ朋毦脂肪酸より $40 \%$ ，艋油高度不饱和酸より $193 \%$ なりき

(4)不溶性沃息化物の組成

カリウス比法に依り夫等のハロゲン含有量を定量せる結果は次の如し

\begin{tabular}{|c|c|c|c|}
\hline 沃 臭 化 物 & 藏 料 & $(A g B r+A g I)(g)$ & $(A g B r+A g I) \%$ \\
\hline 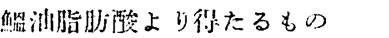 & 0.2145 & 0.3337 & 155.6 \\
\hline 缌油脂盯酒夋 & 0.1573 & 0.2383 & 151.5 \\
\hline ヒラガシラ䐺油脂肪酸 " " & 0.1142 & 0.1742 & 152.5 \\
\hline 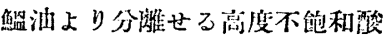 & 0.1985 & 0.3082 & 155.2 \\
\hline
\end{tabular}

次にボビニー, シヤバンヌ雨氏の法に佉り臭素及沃索を定量せる結果は悬素及沃素の比は略 1 に接近したる も一般に思素な過少に欧素は過大なる結果を得たり!(此の力法は舁素或は監素のみを定量する埸合には斯かる

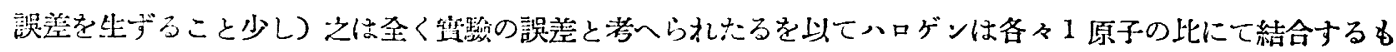

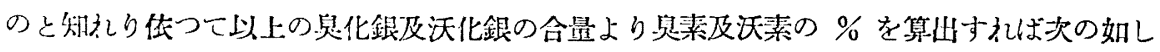

\begin{tabular}{|c|c|c|c|}
\hline 沃 臭 化 物 & $(\mathrm{AgBr}+\mathrm{AgI}) \%$ & $\mathrm{Br} \%$ & $I \%$ \\
\hline 锰油脂肘酸より得たるもの & 155.6 & 29.42 & 46.72 \\
\hline 你油脂肪酸 & 151.5 & 28.65 & 45.50 \\
\hline ヒラガシラ肝油脂肪酸 ” " & 152.5 & 28.84 & 45.82 \\
\hline 鲣油上り分離せる高度不能和酸 & 155.2 & 29.35 & 46.61 \\
\hline
\end{tabular}

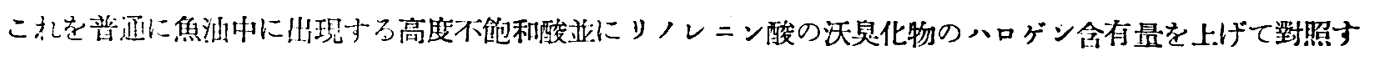


れば

\begin{tabular}{|c|c|c|c|c|}
\hline \multirow{2}{*}{$\begin{array}{l}\mathrm{C}_{18} \mathrm{H}_{28} \mathrm{O}_{2}(1 \mathrm{Br})_{4} \\
\mathrm{C}_{20} \mathrm{H}_{32} \mathrm{O}_{2}(1 \mathrm{Br})_{4}\end{array}$} & $\mathrm{Br} \%$ & \multicolumn{2}{|c|}{$\mathrm{I} \%(\mathrm{AgBr}+\mathrm{AgI}) \%$} & 故に以上生じたる沈澱は高度不飽和酸の 四沃四息 \\
\hline & $\begin{array}{l}28.97 \\
28.25\end{array}$ & $\begin{array}{l}46.01 \\
44.87\end{array}$ & 153.2 & 化物或は五 \\
\hline $\mathrm{C}_{22} \mathrm{H}_{34} \mathrm{O}_{2}(1 \mathrm{Br})_{5}$ & & & & 以下の不飽和酸の沃臭化物は存 \\
\hline $\begin{array}{c}\mathrm{C}_{18} \mathrm{H}_{30} \mathrm{O}_{2}(1 \mathrm{Br})_{3} \\
\mathrm{Cr}^{2}\end{array}$ & 29.28 & 46.51 & 156.3 & 没を澢過し \\
\hline レニン酸 & 26.67 & 42.37 & 141.1 & 二㳐澱を生 \\
\hline
\end{tabular}

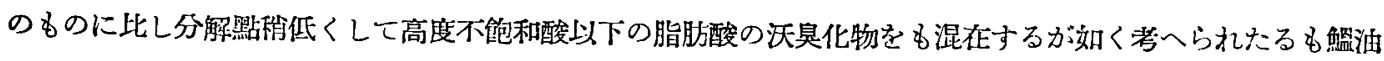
脂肪酸より得たるるのに就きカリゥス氏法に恢りて其のハロゲン含有量を定量せるに
試料
0.1961
$(\mathrm{AgBr}+\mathrm{AgI})(\mathrm{g})$
0.2935
$(\mathrm{AgBr}+\mathrm{AgI}) \%$
149.7

にしてハロゲン含有量は最初のものに比し多少減少を示したり

( 5 ) 亞䁢仁油脂肪酸より生ずる不溶性沃臭化物

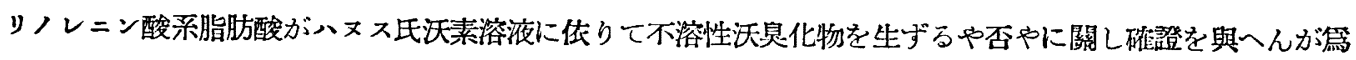

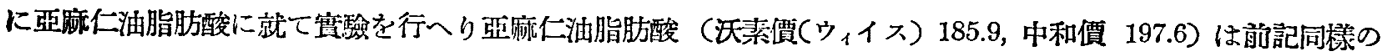
方法に依りて粗大なる不溶性沈洀約 $35 \%$ を生ぜりボビニー, シャバンヌ雨氏の法に依り臭素含有量を定量す るに

$\begin{array}{ccc}\text { 試料 } & \operatorname{AgBr}(\mathrm{g}) & \mathrm{Br} \% \\ 0.1127 & 0.0712 & 26.9\end{array}$

ヌカリウス氏法に依り臭化銀及沃化銀の合量を定量するに

$\begin{array}{ccc}\text { 試料 } & (\mathrm{AgBr}+\mathrm{AgI})(\mathrm{g}) & (\mathrm{AgBr}+\mathrm{AgI}) \% \\ 0.1362 & 0.1927 & 141.5\end{array}$

にして亞麻仁油脂肪酸の主成分たるリノレニン酸三沃三臭化物 $\left(\mathrm{C}_{18} \mathrm{H}_{30} \mathrm{O}_{2}(1 \mathrm{Br})_{3}\right.$ の $\mathrm{Br} \% 26.67,(\mathrm{AgBr}+$ AgI)\% 141.1）の夫に殆ど一致を見たり然して之を加熱する時は $135^{\circ} \mathrm{C}$ 附近に於て六臭化物の如く融解の猋態 を示し次で $140^{\circ} \mathrm{C}$ 附近に於て黑變分解せり故にリノレンン酸系脂肪酸も亦一臭化沃素に依りエーテル並に氷醋 酸不溶性の三沃三臭化物を生ずることを知れる

( 6 吥溶性沃監化物の收率

上記沃監化物の望驗に於て注目すべきは不溶性沃監化物の收率なり一定條件下に於て行ふ時は各魚渵脂肪酸 に閵し其の收率は夫ふ略一定の値を與ふることを知れり此の收率の多少は全く高度不飽和酸の多少に起因寸る を以て此の收率は從來沃素價のみにては滿足に表示し得ざりし魚油の不饱和度の鑑裁に羁し其の一助たらしめ 得ると考へられたるを以て多種魚油に就て此の賽羷を行ひたり其の中適當なりと考へられたる一方法を次に示 于

魚油を脂肪酸となし其の $0.5 \mathrm{~g}$ 附近を小型のフラスコに精棌しエーテル $10 \mathrm{cc}$ に溶解し冷却しつ」 1 モル立

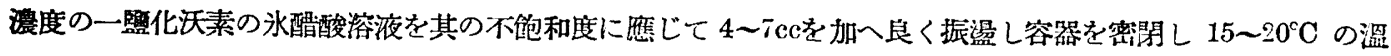

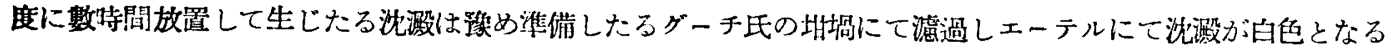

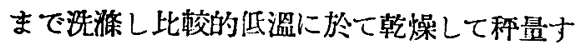

以上の方法に從ひ各璉魚油に就て䒨驗せる結果は次の如し 


\begin{tabular}{|c|c|c|c|c|c|c|c|c|c|}
\hline \multirow[b]{2}{*}{ 魚油䁕肪酸 } & \multicolumn{4}{|c|}{ 原油の特數 } & \multirow[b]{2}{*}{ 魚油脂肪酸 } & \multirow[b]{2}{*}{$\begin{array}{l}\text { 沃覧 } \\
\text { 收率 }\end{array}$} & \multicolumn{3}{|c|}{ 原油の特数 } \\
\hline & $\begin{array}{l}\text { 化物 } \\
\text { 收率 }\end{array}$ & $\begin{array}{l}\text { 沃素筧 } \\
\text { (ウィイ) }\end{array}$ & 醶化儥 & 屈折來 $d^{20}$ & & & 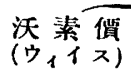 & 鹷化價 & 屈折率 $n_{D}^{20}$ \\
\hline & 43.0 & 180.4 & 195.9 & 1.4805 & 兒鯨䧕油 & 24.1 & 148.5 & 190.8 & 1.4770 \\
\hline 大輩 油 & 7.1 & 108.4 & 186.9 & 1.4728 & 怵香鲸皮油 & 1.6 & 88.1 & 136.6 & 1.4656 \\
\hline 小 瑓 油 & 10.8 & 148.4 & 190.1 & 1.4761 & 抹唓鯨骨油 & 0.8 & 72.7 & 139.8 & 1.4642 \\
\hline シラ & 22.5 & 140.7 & 184.5 & 1.4749 & 抹香鯨䜟油 & 2.7 & 79.9 & 143.9 & 1.4660 \\
\hline 種崖 & 19.0 & 131.7 & 173.8 & 1.4752 & 座頭鯨皮油 & 6.9 & 121.4 & 187.8 & 1.4742 \\
\hline 兄 姃 皮油 & 21.7 & 137.7 & 186.4 & $\begin{array}{l}1.4 / 02 \\
1.4758\end{array}$ & 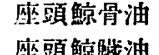 & 13.1 & 113.3 & 191.9 & 1.4728 \\
\hline 兒鯨骨油 & 21.9 & 141.6 & 188.7 & 1.4760 & 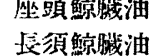 & $\begin{array}{r}15.5 \\
5.1\end{array}$ & $\begin{array}{r}126.6 \\
814\end{array}$ & 187.9 & 1.4748 \\
\hline
\end{tabular}

上上の實駼に依り魚油の沃素價は概して高度不饱和酸の量に支配されつっあること明かなり然して此の收率

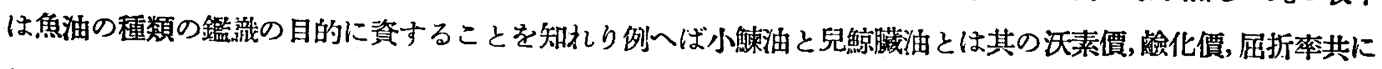
相近接するも沃酮化物つ收率に於ては甚しく相違するを以て其の何れなるかを凅別することを得へし

結 論

（1）魚油脂脂酸エーテル溶液に濃厚なるウィイス氏沃素溶液を加へて生ずる不溶性沈澱は高度不跑和酸の 四沃四龭化物或は五沃五監化物なり

（2）魚油脂肪酸エーテル溶液に濃厚なるハヌス氏沃素溶液を加一て生ずる沈激も亦高度不飽和酸の四沃四 臭化物或は五沃五臭化物のみよりなれり

(3) リノレニン酸系脂肪酸も同樣なる條件の下に於てハヌス氏沃素溶液に恢りて不溶性の三沃三臭化物の 沈澱を生ず

（4）高度不能和酸の沃監化物並に沃臭化物は其の具化物と同樣に加㶻に際して融解狀態を經ずして黑變分

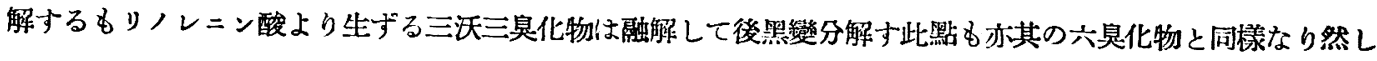
て决等の融解熙並に分解熊は同數の不飽和度のものにありては添加せるハロゲンの全分子量の增加と共に低下 するは興味深き事實なり

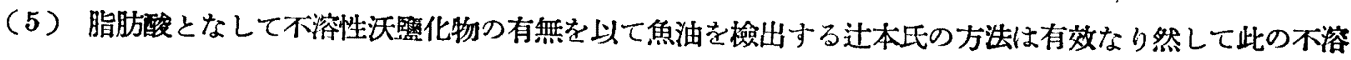
性沃通化物の收率は條件を定むる時は沃素價, 踰化價等と相俟つて魚油の種類の鑑識に資することを得へし

（6）濃厚なるハヌス氏沃素溶液は容易にリノレニン酸沃狊化物をす沈澱せしむるを以てウィイス氏沃素溶 液の如く魚油の检出に利用するには不充分なり然れども此の一臭化沃素溶液に传りては二重結合 2 個以下の脂 肪酸は沈澱を生ずること無きを以て高度不飽和酸を含有せざる植物油脂に於てリノレンン酸系脂肪酸の檢出に は充分にして其の收率は條件を定むる時には臭化物試驗の如くリノレニン酸采脂肪酸含有量を指示する一指針 となすことを得べし

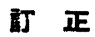

油脂硬化に於て生ずる新化合物に就て（第 4 報）

(第 35 編第 11 册)

頁行 詔 正

1239 下 8 生田氏野及生田氏 